\title{
HUBUNGAN HIGIENE PERSONAL, SANITASI DAN TINGKAT PENGETAHUAN TERHADAP DEMAM TIFOID
}

\author{
Ria Komariah, Dewi Saroh \\ Sekolah Tinggi Ilmu Kesehatan Nasional, Jl. Solo Baki Kwarasan, Sukoharjo, Indonesia \\ *Email: komariahria93@gmail.com
}

\begin{abstract}
ABSTRAK
Demam tifoid masih banyak terjadi di Indonesia termasuk di Kabupaten Ponorogo, Jawa Timur. Pada tahun 2019 terdapat 283 kasuspenyakit tifoid di wilayah kerja Puskesmas Pulung, Kabupaten Ponorogo. Penelitian ini bertujuan untuk mengetahui hubungan higiene personal, sanitasi, dan tingkat pengetahuan terhadap demam tifoid, mengetahui faktor manakah yang berpengaruh terhadap demam tifoid, dan melakukan screening pada santriwati di pondok pesantren wilayah kerja Puskesmas Pulung.Penelitian ini menggunakan metode analitik komparatif secara total sampling yaitu sebanyak 26 santriwati kelas 9 dan 12. Penelitian dilakukan di Pondok Pesantren wilayah kerja Puskesmas Pulung pada Maret hingga Mei 2021. Data diperoleh dari hasil kuesioner dan pemeriksaan widal kemudian dianalisa menggunakan Uji Fisher dengan signifikansi 0,05.Terdapat 16 responden (61,5\%) dengan higiene personal baik dan 10 responden (38,5\%) dengan higiene personal buruk. Sebanyak 17 responden (65,4\%) memiliki sanitasi dan tingkat pengetahuan baik dan sisanya 9 responden (34,6\%) memiliki sanitasi dan tingkat pengetahuan buruk. Berdasarkan ujiyang telah dilakukan, diperoleh hasil uji Fisher pada higiene personal $(p=0,420, p>\alpha)$, sanitasi $(p=1,00, p>\alpha)$, dan tingkat pengetahuan $(p=1,00, p>\alpha)$. Nilai $p$ pada ketiga variabel lebih besar daripada nilai $\alpha$, sehingga dapat diambil kesimpulan bahwa tidak ada hubungan higiene personal, sanitasi, dan tingkat pengetahuan terhadap demam tifoid.
\end{abstract}

Kata kunci : Higiene personal; sanitasi; pengetahuan; tifoid

\begin{abstract}
Typhoid fever is still common in Indonesia, including in Ponorogo Regency, East Java. In 2019 there were 283 cases of typhoid in Pulung Health Center, Ponorogo Regency. This study aims to determine the relationship of personal hygiene, sanitation, and knowledge level to typhoid fever, to find out which factors affect typhoid fever, and screening students in Islamic boarding schools in the working area of Pulung Health Center.This study uses a comparative analytic method with total sampling of 26 students in grades 9 and 12. The study was conducted at Islamic boarding schools in the working area of the Pulung Health Center from March to May 2021. The data obtained from the questionnaire and Widal examination were then analyzed using Fisher's exact test with a significance of 0,05. There are 16 respondents $(61.5 \%)$ with good personal hygiene and 10 respondents (38.5\%) with poor personal hygiene. There are 17 respondents $(65.4 \%)$ with good sanitation and knowledge level, 9 respondents $(34.6 \%)$ have poor sanitation and knowledge level. Based on the tests, the results of Fisher exact test are obtained on personal hygiene $(p=0.420, p>\alpha)$, sanitation $(p=1.00, p>\alpha)$, and knowledge level $(p=1.00, p>\alpha)$. The $p$ value for three variables is bigger than $\alpha$, so it can be concluded that there is no relationship between personal hygiene, sanitation, and knowledge level to typhoid fever.
\end{abstract}

Keywords: Personal hygiene, sanitation, knowledge, tyfoid

Universitas Sari Mutiara Indonesia

DOI : https://doi.org/10.51544/jalm.v6i2.2115 


\section{PENDAHULUAN}

Demam tifoid merupakan penyakit infeksi akut bersifat sistemik yang disebabkan oleh mikroorganisme Salmonella enterica serotipe typhi yang dikenal dengan Salmonella typhi. (Idrus, 2020). Hingga saat ini penyakit demam tifoidmasih merupakan masalah kesehatan di negara-negara tropis termasuk Indonesia (Sundari et al, 2021). Berdasarkan hasil Riset Kesehatan Dasar 2007, prevalensi nasional Tifoid (berdasarkan diagnosis tenaga kesehatan dan keluhan responden) adalah 1,60\%.Angka prevalensi tifoid di Provinsi Jawa Timur sebesar 1,13\%. Angka ini tidak melebihi prevalensi nasional, namun kasus demam tifoid di Jawa Timur masih cukup tinggi.

Berdasarkan data yang diperoleh dari Dinas Kesehatan Kabupaten Ponorogo, pada tahun 2019 terdapat 4649 kasus demam tifoid di Kabupaten Ponorogo. Jumlah penyakit tifoid di wilayah kerja Puskesmas Pulung pada tahun 2019 terdapat 283 kasus. Pada tahun 2020 angka kejadian demam tifoid di salah satu pondok di wilayah kerja Puskesmas Pulung adalah $10,1 \%$.

Penelitian ini secara umum bertujuan untuk mengetahui hubungan higiene personal, sanitasi, dan tingkat pengetahuan terhadap demam tifoid. Penelitian ini mendukung penelitian Raynaldi Pangestu (2020) mengenai Perilaku Higienitas Santri dan Angka Kejadian Karier Demam Tifoid di Pondok Pesantren Ash Sholihah Sleman, bahwa sebagian besar santri memiliki perilaku higienitas yang baik, namun masih terdapat santri dengan status karier demam tifoid yang dapat menyebabkan transmisi pada santri lainnya. Hasil penelitian ini secara teoritis diharapkan dapat menjadi bahan kajian bagi peneliti lain untuk memahami hubungan higiene personal, sanitasi, dan tingkat pengetahuan terhadap demam tifoid.

Bakteri S. typhi masuk ke dalam tubuh manusia melalui makanan yang tercemar, kemudian menembus mukosa usus masuk ke kelenjar limfe usus (Nasronudin, 2011). Cara penyebarannya melalui muntahan, urin, dan kotoran dari penderita yang kemudian secara pasif terbawa oleh lalat (kaki-kaki lalat). Lalat itu mengkontaminasi makanan, minuman, sayuran, maupun buah-buahan segar (Suhaemi, 2010). Makan makanan yang tidak dimasak atau dimasak tidak sempurna (tidak matang) dapat menyebabkan bakteri ini tetap hidup dan masuk ke dalam tubuh bersama makanan.Tubuh akan melakukan mekanisme pertahanan melalui beberapa proses respon imun baik lokal maupun sistemik, spesifik dan non-spesifik serta humoral dan seluler (Idrus, 2020).

Higiene personal dapat diartikan sebagai suatu perilaku yang mencerminkan upaya dalam diri suatu individu untuk mempertahankan kebersihan pada dirinya, sehingga tidak mudah terjangkit penyakit dan kesehatan dapat dijaga dengan baik (Lavenia, 2019).Higiene personal adalah faktor yang sangat penting karena diri kita merupakan penghantar vektor penyakit dan dalam makanan merupakan penyebab penyakit (Simanjuntak, 2010).

Sanitasi adalah suatu usaha pencegahan penyakit (preventif) yang menitikberatkan kegiatannya kepada usaha-usaha kesehatan lingkungan hidup manusia (Simanjuntak, 2010). Beberapa hal yang termasuk dalam ruang lingkup sanitasi ialah sebagai berikut: penyediaan air bersih atau air minum, pengolahan sampah, pengolahan makanan dan minuman, pengawasan dan/atau pengendalian serangga serta binatang pengerat, kesehatan dan juga keselamatan kerjamelakukan kegiatan atau aktivitas K3 melingkupi ruang kerja, pekerjaan, cara kerja, serta juga tenaga kerja (Fahri, 2021).

\section{METODE PENELITIAN}

Penelitian ini menggunakan metode penelitian analitik komparatif, yaitu dengan membandingkan beberapa variabel (higiene personal, sanitasi, dan tingkat pengetahuan) terhadap demam tifoid. Data diperoleh dengan menggunakan kuesioner sebagai instrumen untuk variabel higiene personal, sanitasi, dan tingkat pengetahuan, serta dilakukan 
pemeriksaan widal untuk memperoleh data mengenai demam tifoid. Data yang sudah ada kemudian dilakukan uji normalitas untuk mengetahui apakah data memiliki sebaran normal atau tidak. Jika data memiliki sebaran normal maka analisa data dilakukan dengan Uji Chi-square, namun jika sebaran data tidak normal, maka digunakan uji Fisher.

Subjek penelitian adalah santriwati pondok pesantren di wilayah kerja Puskesmas Pulung. Objek penelitian adalah demam tifoid, higiene personal, sanitasi serta tingkat pengetahuan santriwati. Pengambilan sampel pada penelitian ini dilakukan dengan total sampling pada seluruh santriwati kelas 9 dan kelas 12 yang bersedia menjadi responden penelitian.

Alat yang digunakan dalam penelitian ini adalah kuesioner, APD, centrifuge, rotator, tornikuet, mikropipet, dantimer. Bahan yang digunakan adalah reagen widal, darah vena, tabung vakum, spuit, kapas alkohol, plester, kaca obyek, dan tusuk gigi.

Penulis dibantu pihak pondok menjelaskan kepada santriwati mengenai kegiatan yang akan dilaksanakan dan meminta persetujuan kepada santriwati. Penulis memberikan lembar persetujuan (informed consent) kepada santriwati yang bersedia menjadi responden. Penulis meminta responden untuk mengisi kuesioner dan mengambil darahnya serta melakukan pemeriksaan widal..

\section{HASIL DAN PEMBAHASAN}

Penelitian ini dilakukan di Pondok Pesantren wilayah kerja Puskesmas Pulung sedangkan pemeriksaan widal dilakukan di Laboratorium Puskesmas Pulung. Sampel pada penelitian ini adalah seluruh santriwati kelas 9 dan kelas 12 yang bersedia menjadi responden penelitian.

Jumlah santriwati kelas 9 dan 12 adalah 29 orang, namun yang bersedia menjadi responden sebanyak 26 orang.

Pada penelitian ini kuesioner diuji kevalidannya dengan menggunakan koefisien reprodusibilitas $(\mathrm{Kr})$ dan koefisien skalabilitas (Ks). Uji koefisien reprodusibilitas $(\mathrm{Kr})$ dan koefisien skalabilitas (Ks) dilakukan dengan menggunakan aplikasi SKALO Program Analisis Skala Guttmann. Hasil uji koefisien reprodusibilitas pada kuesioner higiene personal diperoleh nilai 0,95, sedangkan koefisien skalabilitas 0,90. Pada kuesioner sanitasi diperoleh koefisien reprodusibilitas 0,97 dan koefisien skalabilitas 0,94. Hasil uji koefisien reprodusibilitas pada kuesioner tingkat pengetahuan diperoleh nilai 0,98 , sedangkan koefisien skalabilitas 0,97. Kuesioner dikatakan valid karena memiliki koefisien reprodusibilitas $>0,9$ dan skalabilitas $>0,6$.

Uji reliabilitas pada instrumen dilakukan dengan menggunakan uji KR 20. Instrumen dikatakan reliabel jika nilai koefisien reliabilitas KR lebih dari 0,7 (Fraenkel, 2012). Pada kuesioner higiene personal diperoleh hasil KR 20 sebesar 0,72. Pada kuesioner sanitasi diperoleh hasil KR 20 sebesar 0,84. Pada kuesioner tingkat pengetahuan diperoleh hasil KR 20 sebesar 0,73 sehingga dapat dikatakan bahwa kuesioner memiliki reliabilitas baik.

Distribusi responden berdasarkan karakteristik serta variabel-variabel yang dilakukan penelitian dapat dilihat pada tabel 1 berikut:

Tabel 1. Responden Berdasarkan Karakteristik

\begin{tabular}{lcccccc}
\hline \multirow{2}{*}{ Karakteristik } & \multicolumn{2}{c}{ Tifoid Positif } & \multicolumn{2}{c}{ Tifoid Negatif } & \multirow{2}{*}{ Total } & \multirow{2}{*}{$\%$} \\
\cline { 2 - 4 } & $\mathrm{N}$ & $\%$ & $\mathrm{~N}$ & $\%$ & & \\
\cline { 1 - 4 } Pendidikan & 5 & 19,2 & 13 & 50,0 & 18 & 69,2 \\
$\quad$ SMP & 3 & 11,5 & 5 & 19,2 & 8 & 30,8 \\
$\quad$ SMK & & & & & & \\
Higiene personal & 6 & 23,1 & 10 & 38,4 & 16 & 61,5 \\
$\quad$ Baik & 2 & 7,7 & 8 & 30,8 & 10 & 38,5 \\
$\quad$ Buruk & & & & & & \\
Sanitasi & 5 & 19,2 & 12 & 46,2 & 17 & 65,4 \\
$\quad$ Baik & 3 & 11,5 & 6 & 23,1 & 9 & 34,6 \\
$\quad$ Buruk & & & &
\end{tabular}

Universitas Sari Mutiara Indonesia

DOI : https://doi.org/10.51544/jalm.v6i2.2115 
Tingkat Pengetahuan

$\begin{array}{lcccccc}\text { Baik } & 5 & 19,5 & 12 & 46,2 & 17 & 65,4 \\ \text { Buruk } & 3 & 11,5 & 6 & 23,1 & 9 & 34,6\end{array}$

Tabel 1 menunjukkan bahwa terdapat 16 responden $(61,5 \%)$ dengan higiene personal baik dan 10 responden $(38,5 \%)$ dengan higiene personal buruk. Sebanyak 17 responden $(65,4 \%)$ memiliki sanitasi dan tingkat pengetahuan baik dan sisanya 9 responden (34,6\%) memiliki sanitasi dan tingkat pengetahuan buruk.

Uji normalitas data pada penelitian ini menggunakan Shapiro-Wilk karena jumlah sampel kecil yaitu $\leq 50$. Setelah dilakukan uji normalitas diketahui bahwa data berdistribusi tidak normal karena nilai kemaknaan $p<0,05$ sehingga uji statistik yang digunakan adalah uji Fisher.

Berdasarkan ujiFisheryang telah dilakukan, diperoleh hasil pada higiene personal $(p=0,420, p>\alpha)$, sanitasi $(p=1,00, p>\alpha)$, dan tingkat pengetahuan $(p=1,00, p>\alpha)$. Nilai $p$ pada ketiga variabel lebih besar daripada nilai $\alpha$, sehingga dapat diambil kesimpulan bahwa tidak ada hubungan higiene personal, sanitasi, dan tingkat pengetahuan terhadap demam tifoid.

Pada tabel 1 terdapat 6 responden $(23,1 \%)$ yang memiliki personal higiene baik dengan hasil tifoid positif dan terdapat 2 responden $(7,7 \%)$ yang memiliki personal higiene buruk dengan tifoid positif. Meskipun memiliki higiene personal yang baik, tetapi 6 responden memiliki hasil tifoid positif. Hal ini tidak jauh berbeda dengan penelitian Pangestu (2020).

Pada penelitian Pangestu (2020) diperoleh kesimpulan sebagian besar santri memiliki perilaku higienitas yang baik, namun masih terdapat santri dengan status karier demam tifoid yang dapat menyebabkan transmisi pada santri lainnya. Hal ini juga terjadi pada responden penelitian ini, meskipun santriwati memiliki personal higiene baik, tetapi masih ada $23,1 \%$ santriwati yang memiliki hasil tifoid positif. Santriwati ini dapat disebut sebagai karier demam tifoid.

Pada tabel 1 terdapat 5 responden $(19,2 \%)$ yang memiliki sanitasi baik dengan hasil tifoid positif dan terdapat 3 responden $(11,5 \%)$ dengan sanitasi buruk dengan tifoid positif.
Hasil dari penelitian ini tidak sejalan dengan penelitian Artanti (2012) yang menunjukkan bahwa ada hubungan antara sarana pembuangan tinja, kebiasaan mencuci tangan sebelum makan dengan kejadian demam tifoid.

Ruang lingkup sanitasi ada beberapa hal, diantaranya adalah penyediaan air bersih atau air minum (water supply), pengolahan sampah (refuse disposal), pengolahan makanan dan minuman (food sanitation), pengawasan dan/atau pengendalian serangga serta binatang pengerat (insect and rodent control), kesehatan dan juga keselamatan kerja melakukan kegiatan atau aktivitas K3 (Fahri, 2021).

Pada penelitian ini penulis lebih fokus terhadap tersedianya air bersih, sarana pembuangan tinja dan kebersihan lingkungan dari sampah. Tidak menutup kemungkinan adanya karier tifoid disebabkan oleh hal lain seperti pengolahan sampah, pengolahan makanan, pengawasan/pengendalian serangga dan binatang pengerat.

Pada tabel 1 terdapat 5 responden $(19,2 \%)$ yang memiliki pengetahuan baik dengan hasil tifoid positif dan terdapat 3 responden $(11,5 \%)$ dengan pengetahuan buruk dengan tifoid positif. Hasil penelitian ini tidak sejalan dengan penelitian Putri (2018). Pada penelitian Putri (2018), diperoleh bahwa pendidikan seseorang dapat meningkatkan pengetahuannya tentang kesehatan, semakin tinggi tingkat pendidikan semakin mudah menyerap informasi dan dapat juga menerapkan kebiasaan hidup bersih sehat. Hasil pada penelitian yang penulis lakukan, pengetahuan seseorang mengenai tifoid tidak menjamin bahwa dirinya dapat terhindar dari demam tifoid.

Kelemahan pada penelitian ini adalah kuesioner yang digunakan tidak terstandar. Pembuatan kuesioner ini sebenarnya mengacu pada beberapa kuesioner KAP (Knowledge, Attitude, Practice) mengenai higiene, sanitasi, dan tifoid, namun penulis tidak menggunakan keseluruhan pertanyaan kuesioner dikarenakan alasan ketidaksesuaian pertanyaan dengan 
kondisi di pondok pesantren. Hal ini menyebabkan alat ukur (kuesioner) menjadi tidak terstandarisasi sehingga hasil penelitian ini tidak sesuai dengan kerangka pikir penelitian.

Penggunaan skala Guttmann yang memiliki pilihan jawaban hanya ya dan tidak terlalu mudah, sehingga menyebabkan responden kurang mencermati soal pada kuesioner yang diberikan. Pada saat pengisian kuesioner, penulis memberikan pengarahan di awal, lalu kuesioner diisi sendiri oleh santriwati, namun masih ada santriwati yang bingung dalam melakukan pengisian kuesioner dan mengisi tidak sesuai dengan kondisi sebenarnya.

Adanya pandemi Covid-19 juga menjadi salah satu keterbatasan dalam penelitian ini. Pemberlakuan Pembatasan Kegiatan Masyarakat (PPKM) menyebabkan santriwati yang masuk pondok dibatasi, sehingga hanya terdapat santriwati kelas 9 dan 12 saja. Populasi penelitian yang awalnya adalah seluruh santriwati berubah menjadi santriwati kelas 9 dan 12 saja sehingga sampel penelitian kurang representatif.

\section{SIMPULAN}

Berdasarkan penelitian dengan judul "Hubungan Higiene Personal, Sanitasi, dan Tingkat Pengetahuan terhadap Demam Tifoid" yang dilakukan di Pondok Pesantren wilayah kerja Puskesmas Pulung dapat diambil simpulan yaitu:

1. Tidak ada hubungan higiene personal, sanitasi, dan tingkat pengetahuan terhadap demam tifoid.

2. Hasil screening terhadap 26 santriwati diperoleh sebanyak 8 orang $(30,8 \%)$ memiliki hasil tifoid positif.

Hendaknya peneliti selanjutnya dapat mengganti kuesioner dengan menggunakan skala lain, misalnya skala likert dan menggunakan alat ukur terstandar serta teknik pengambilan data dilakukan dengan interview/ wawancara langsung kepada responden.

\section{UCAPAN TERIMA KASIH}

Penelitian ini merupakan penelitian yang dilaksanakan di Pondok Pesantren wilayah

Universitas Sari Mutiara Indonesia

DOI : https://doi.org/10.51544/jalm.v6i2.2115 kerja Puskesmas Pulung, oleh karena itu penulis mengucapkan terimakasih kepada Bapak Subhan Fathu Alam selaku pemilik Pondok Pesantren. Penulis juga mengucapkan terimakasih kepada Bapak Oga Sugianto yang banyak membantu selama kegiatan penelitian ini berlangsung. Harapan penulis semoga hasil penelitian ini dapat bermanfaat khususnya bagi santriwati danPondok Pesantren wilayah kerja Puskesmas Pulung.

\section{DAFTAR PUSTAKA}

Artanti, N. W. 2012. Hubungan antara Sanitasi Lingkungan Hygiene Perorangan dan Karakteristik Individu dengan Kejadian Demam Tifoid di Wilayah Kerja Puskesmas Kedungmundu Kota Semarang Tahun 2012. Skripsi. Jurusan Ilmu Kesehatan Masyarakat Fakultas Ilmu Keolahragaan Universitas Negeri Semarang.

Balitbangkes Depkes RI. 2008. Riset Kesehatan Dasar (RISKESDAS) 2007. Jakarta: Balitbangkes Depkes RI

Fahri, S. 2021. Sanitasi Total Berbasis Masyarakat. Jakarta: PT Gramedia

Fraenkel, J.R., Wallen, N.E., Hyun, H.H. 2012. How to design and evaluate research in education eighth edition. New York : Mc Graw Hill.

Idrus, H. H. 2020. Buku Demam Tifoid Hasta 2020 . Makasar: Universitas Muslim Indonesia

Lavenia, C. \& Dyasti, J. A. 2019. Studi Komparatif Personal Hygiene Mahasiswa Universitas Indonesia di Indekos dan Asrama. Jurnal KSM Eka Prasetya UI Volume 1, Number 4.

Nasronudin. 2011. Penyakit Infeksi di Indonesia Solusi Kini \& Mendatang. Surabaya: Pusat Penerbitan dan Percetakan UNAIR (AUP).

Pangestu, R. 2020. Perilaku Higienitas Santri dan Angka Kejadian Karier Demam Tifoid di Pondok Pesantren Ash Sholihah, Sleman. Karya Tulis Ilmiah. Fakultas Kedokteran Universitas Islam Indonesia.

Pom, Chreay. 2010. National Sanitation and Hygiene Knowledge, Attitudes, and Practices (KAP) Survey. Phnom Penh, 
Cambodia: Department of Rural Health Care Ministry of Rural Development.

Putri, N. K. S. W., Yaroseray, M. M., \& Rohmani. 2018. Faktor yang Mempengaruhi Penularan Typhoid Abdominalis pada Pasien yang Berobat di Klinik Doa Bunda Kabupaten Jayapura. Jurnal Keperawatan Tropis Papua. Volume 01 Nomor 02 Desember 2018 ISSN 2654 5756 halaman 67-68.

Simanjuntak, L. 2013. Sanitasi, Hygiene, dan Keselamatan Kerja halaman 8.

Suhaemi. 2010. Faktor-faktor yang Berhubungan dengan Kejadian Demam Tyfoid di RSUD Syekh Yusuf Kab. Gowa. Skripsi. Jurusan Keperawatan Fakultas Ilmu Kesehatan Universitas Islam Negeri (Uin) Alauddin Makassar.

Sundari, M., Debie, R., \& Grace, J, B. 2021. Identifikasi Bakteri Salmonella sp pada Penderita Demam Tifoid Anak Usia 5-14 Tahun dengan Metode Widal Test di Rumah Sakit Advent Medan Tahun 2018. Jurnal Analisis Laboratorium Medik. Vol 6: Nomor 1: 6-12.

Widhiarso, W. 2011. SKALO : Program Analisis Skala Guttman. Program Komputer. Yogyakarta : Fakultas Psikologi Universitas Gadjah Mada 